\title{
SANKSI PROSTITUSI ONLINE PERSPEKTIF HUKUM ISLAM
}

\author{
\begin{tabular}{r|l} 
Ria Zumaroh & $\begin{array}{l}\text { Sumberwaru Wringinanom Gresik } \\
\text { riazumaroh@ymail.com }\end{array}$ \\
& RT 4 RW 3 Wringinanom \\
Kab. Gresik
\end{tabular}
}

\begin{abstract}
This article discusses Islamic penal law perspective on the punishment of online prostitution through social media. In practice, the legal basis of punishing pimps is the Penal Code article 296 with the maximum of 1 year and 4 months of imprisonment or maximum fine of fifteen thousand rupiahs, article 506 with maximum one year of imprisonment. The Penal Code article 284 also punishes prostitutes who act in voluntary adultery. Likewise, the Law No. 112008 on electronic information and transaction article 27 (1) states that the felon of this crime is punished with maximum of six year of imprisonment or maximum fine of one billion rupiahs. This punishment is considered lenient and not making felon learning any lesson for his/her wrong doing. In Islamic penal law, online prostitution is considered jarîmah ta'zîr because there is no textual reference on this crime. Judges is authorized to decide punishment for the felon of this jarîmah ta'zîr.
\end{abstract}

Keywords: punishment, online prostitution, social media, Islamic law

Abstrak: Artikel ini membahas tentang sanksi prostitusi online melalui media sosial dilihat dari perspektif hukum Islam. Dasar hukum yang digunakan dalam menjerat mucikari adalah Kitab Undang-Undang Hukum Pidana Pasal 296 yaitu pidana penjara paling lama satu tahun empat bulan atau pidana denda paling banyak lima belas ribu rupiah; dan Pasal 506 yakni pidana kurungan paling lama satu tahun. Bagi seorang PSK, Kitab Undangundang Hukum Pidana menyebutkannya sebagai pesenggamaan atas dasar suka sama suka, yang dilakukan oleh seseorang dengan orang yang telah bersuami atau beristri (permukahan) sebagaimana yang terdapat dalam Pasal 284 KUHP. Adapun dalam Undang-Undang No.11 Tahun 2008 tentang Informasi dan Transaksi Elektronik Pasal 27 Ayat (1), dijerat dengan ancaman pidana penjara paling lama 6 tahun dan atau denda paling banyak Rp.1.000.000.000,00 (satu miliar rupiah). Sanksi ini dirasa kurang memberikan efek jera kepada pelaku. Dalam hukum pidana Islam, tindak pidana prostitusi online termasuk dalam kategori jarîmah ta'zîr, karena tidak ada ketentuan nash mengenai tindak pidana ini. Hakim diberi kewenangan untuk menjatuhkan hukuman bagi pelaku jarîmah ta'zîr.

Kata Kunci: Sanksi, prostitusi online, media sosial, hukum Islam. 


\section{Pendahuluan}

Seiring perkembangan zaman, pengetahuan seseorang mengenai komputer semakin meningkat, khususnya teknologi informasi dan komunikasi. Teknologi memang membawa dampak yang besar terhadap kehidupan manusia sekarang ini. Kecanggihan teknologi membuat informasi yang ada dari belahan duniapun segera bisa diakses atau didapatkan, apalagi dengan adanya internet.

Perkembangan internet bagaikan dua sisi mata uang, pada satu sisi ia berdampak positif yang berfungsi untuk memudahkan manusia dalam berinteraksi, bertukar informasi dalam berbagai aktifitasnya dan menambah tren perkembangan teknologi dengan segala bentuk kreatifitas manusia. Pada saat bersamaan dampak negatifnya tidak bisa dihindari. Berbagai muatan pornografi dan perilaku asusila banyak yang menggunakan media internet. Perkembangan internet yang semakin canggih mengakibatkan munculnya kejahatan melalui jejaring internet (cyber crime). Salah satu jenis kejahatan ini adalah prostitusi melalui internet atau disebut prostitusi online.

Prostitusi merupakan masalah yang sangat rumit. Banyak hal yang berhubungan di dalamnya, sehingga masalah ini perlu perhatian khusus dari masyarakat. Prostitusi, sebuah bisnis yang identik dengan dunia hitam ini merupakan salah satu bisnis yang mendatangkan uang dengan sangat cepat, dan tidak dibutuhkan banyak modal untuk melakukan hal tersebut. Hanya cukup dengan modal tubuh yang secara profesional bersedia untuk dibisniskan. Dampak prostitusi bukan hanya berdampak pada pelakunya saja tetapi juga berimbas pada masyarakat luas. Agama sebagai pedoman dalam hidup sama sekali tidak dihiraukan oleh mereka yang terlibat di dalam praktek prostitusi ini dan benar-benar merupakan perbuatan yang dilarang agama. Prostitusi yang dikenal juga dengan pelacuran, bukan hanya sebuah gejala individu, akan tetapi sudah menjadi gejala sosial dari penyimpangan seksualitas yang normal dan juga agama.

Dalam prostitusi terdapat tiga komponen penting yakni pelacur (prostitute), mucikari atau germo (pimp) dan pelanggannya (client). Bisnis prostitusi ini dapat dilakukan secara konvensional maupun melalui dunia maya. Terungkapnya beberapa kasus oleh pihak kepolisian menandakan maraknya kasus cyber porn melalui situs-situs jejaring sosial.

Berbicara tentang prostitusi adalah berbicara tentang peradaban itu sendiri yang usianya hampir sama tuanya dengan usia kehidupan manusia. 
Dengan kata lain, prostitusi tidak akan pernah bisa dihapuskan. Sebagaimana yang disampaikan oleh Trisnadi bahwa adakalanya kita tidak bisa memahami bahwa pada saat itulah kita akan bisa memahami bahwa prostitusi tidak bisa dipandang secara hitam putih. ${ }^{1}$

Islam memandang bahwa perbuatan prostitusi merupakan perbuatan tercela dan termasuk dalam dosa besar dan mempunyai sanksi yang besar. Islam tidak membedakan apakah tindakan tersebut atas dasar suka sama suka, paksaan, tidak beda pula, apakah ada tuntutan ke pengadilan ataupun tidak, semuanya dipandang sebagai perbuatan zina. Bahkan dalam al-Qur'an disebutkan bahwa perbuatan mendekati zina saja dilarang. Perbuatan mendekati zina disebut sebagai perbuatan cabul yang dapat menyebabkan dan mengakibatkan terjadinya suatu perbuatan zina. ${ }^{2}$ Dalam al-Qur'an, larangan perbuatan mendekati zina terdapat dalam surat al-Isra ayat 32 yang artinya:

"Dan janganlah kamu mendekati zina, sesungguhnya zina itu adalah suatu perbuatan yang keji dan suatu jalan yang buruk."

Alasan-alasan larangan melakukan perbuatan mendekati zina, menurut para mufasirin dari Tim Pentashih Mushaf al-Qur'an Departemen Agama Republik Indonesia, adalah karena perbuatan zina merupakan perbuatan keji yang mengakibatkan kerusakan, antara lain: ${ }^{3}$

1. Perbuatan zina dapat mencampuradukkan keturunan yang mengakibatkan seseorang menjadi ragu-ragu terhadap anaknya. Apakah anak yang lahir itu adalah keturunannya yang sah atau hasil perzinaan. Dugaan suami terhadap istri melakukan zina dengan lakilaki lain dapat menimbulkan kesulitan-kesulitan dalam hal kedudukan hukum anak yang bersangkutan. Hal ini dapat mengakibatkan terhambatnya kelangsungan keturunan dan menghancurkan tata kemasyarakatan.

2. Perbuatan zina menimbulkan ketidakstabilan dan kegelisahan di antara sesama anggota masyarakat disebabkan tidak terpeliharanya kehormatan. Akibat terjadinya perbuatan zina banyak menimbulkan terjadinya tindak pidana terhadap nyawa atau pembunuhan dalam masyarakat.

\footnotetext{
${ }^{1}$ Trisnadi, Dolly Hitam Putih Prostitusi, (Surabaya: Gagas Media, 2004), 2.

${ }^{2}$ Neng Djubaedah, Perzinaan dalam Peraturan Perundang-undangan di Indonesia Ditinjau dari Hukum Islam, (Jakarta: Kencana, 2010), 73.

3 Departemen Agama RI, Al-Qur'an dan Tafsirnya, jilid 6, (Semarang: Wicaksana, 1994), 568-569.
} 
3. Perbuatan zina dapat merusak ketenangan hidup berumah tangga. Seorang wanita atau seorang lelaki yang telah berbuat zina menimbulkan stigma atau noda keluarga dalam masyarakat setempat, sehingga memunculkan ketidakharmonisan dan tidak ada kedamaian serta tidak ada ketenangan dalam hubungan hidup berumah tangga, terlebih lagi jika zina itu dilakukan oleh suami atau istri yang bersangkutan.

4. Perbuatan zina dapat menghancurkan kehidupan rumah tangga atau keluarga yang bersangkutan. Hal itu karena suami atau istri yang melakukan zina berarti ia telah menodai keluarga atau rumah tangganya, sehingga akan sukar untuk dielakkan dari kehancuran rumah tangga.

Larangan melakukan pekerjaan mucikari berkaitan dengan larangan terhadap perdagangan perempuan, baik dewasa maupun anak-anak. ${ }^{4}$ Dalam hukum Islam, berdasarkan ketentuan dalam surat an-Nur ayat 33, pekerjaan mucikari hukumnya adalah haram.

"Dan janganlah kamu paksa budak-budak perempuanmu melakukan pelacuran (al-bighâ), sedangkan mereka sendiri menginginkan kesucian, karena kamu hendak mencari keuntungan duniawi. Dan barang siapa yang memaksa mereka, maka sesungguhnya Allah adalah Maha Pengampun dan Maha Penyayang (kepada mereka yang dipaksa melakukan pelacuran) sesudah mereka dipaksa itu." ${ }^{5}$

Larangan melakukan pekerjaan mucikari dalam surat an-Nur ayat 33 didahului oleh perintah dalam surat an-Nur ayat 32, agar kita mengawinkan atau menganjurkan orang-orang yang berstatus sendirian melakukan perkawinan. Dan jika mereka miskin, menurut ayat 32 tersebut, Allah akan memampukan mereka dengan karunia-Nya.

Pada awal ayat 33 surat an-Nur dikemukakan bahwa bagi orang yang tidak mampu melakukan perkawinan hendaklah menjaga kesucian dirinya, sehingga Allah memberikan kemampuan kepada mereka melalui karunia-Nya. Antara surat an-Nur ayat 32 dan 33 sangat berkaitan, karena kedua ayat tersebut mengatur agar orang menjaga kesucian dirinya dari perbuatan zina melalui lembaga perkawinan. Dalam perintah Allah tersebut mengandung larangan berbuat zina. Selain larangan melakukan tindak pidana perzinaan, dalam ayat 33 secara tegas diatur pula tentang

\footnotetext{
${ }^{4}$ Neng Djubaedah, Pornografi dan Pornoaksi ditinjau dari Hukum Islam, (Jakarta: Kencana, 2009), 200.

${ }^{5}$ Departemen Agama RI, Al-Qur'an dan Tafsirnya, 589.
} 
larangan melakukan pekerjaan mucikari yang menyediakan pelacur untuk perzinaan dan pelacuran.

Dalam surat an-Nur ayat 33 tidak diatur secara jelas tentang sanksi terhadap mucikari, meskipun demikian, tidak berarti bahwa bagi para mucikari tidak ada hukumannya. Sanksi terhadap mereka dapat ditentukan melalui lembaga ta'zîr, karena setiap perbuatan maksiat yang tidak dapat dikenai sanksi hudûd (termasuk di dalamnya qishâsh) atau kaffarah dikualifikasikan sebagai jarîmah ta'zîr. ${ }^{6}$ Dengan ukuran dan jenis sanksi yang preventif, agar mereka jera dan tidak berusaha mengulangi perbuatan maksiat itu lagi. Misalnya, selain dijatuhi hukuman penjara, ia juga dijatuhi hukuman denda berupa sejumlah uang halal yang wajib dibayar kepada korban, atau berupa restitusi. ${ }^{7}$

Hukuman ta'zîr adalah hukuman yang belum ditetapkan oleh syara' dan diserahkan kepada ulil amri untuk menetapkannya. Hukuman ta'zîr ini jenisnya beragam, namun secara garis besar dapat dikelompokkan kepada empat kelompok, yaitu sebagai berikut : 8

1. Hukuman ta'zîr yang mengenai badan, seperti hukuman mati dan jild (dera).

2. Hukuman yang berkaitan dengan kemerdekaan seseorang, seperti hukuman penjara dan pengasingan.

3. Hukuman ta'zîr yang berkaitan dengan harta, seperti denda, penyitaan/peramapasan harta, dan penghancuran barang.

4. Hukuman-hukuman lain yang ditentukan oleh ulil amri demi kemaslahatan umum.

Adanya prostitusi biasanya dilakukan di sebuah tempat, baik di pinggiran jalan, pinggir rel, dengan cara pelaku menjajakan diri dan menunggu pelanggan pengguna jasanya datang. Dengan perkembangan ilmu pengetahuan dan teknologi yang semakin canggih serta pengaruh globalisasi cara-cara yang dilakukan dalam bertransaksi sudah bermacammacam, tidak lagi dengan saling bertemu di tempat biasanya menjajakan diri. Dengan menggunakan media internet adalah salah satunya.

Orang yang menyelidiki gejala-gejala kemasyarakatan di Indonesia, tentu akan mengetahui pula bagaimana seseorang sampai melacurkan diri.

\footnotetext{
${ }^{6}$ Jaih Mubarak dan Enceng Arif Faizal, Kaidah Figh Jinayah (Asas-asas Hukum Pidana Islam), (Bandung: Pustaka Bani Quraisy, 2004), 176.

${ }^{7}$ Neng Djubaedah, Pornografi dan Pornoaksi ditinjau dari Hukum Islam, 201.

${ }^{8}$ Ahmad Wardi Muslich, Hukum Pidana Islam, (Jakarta: Sinar Grafika,2005), 258.
} 
Banyak faktor dari dalam dan dari luar yang memainkan peranan dalam proses terjadinya pelacuran itu. Faktor-faktor dari dalam memainkan peran di dalam riwayat si pelacur. Sebagian besar dari pelacur-pelacur itu tidak sempurna rohaninya.?

Melihat kenyataan tersebut menjadikan masalah ini menarik untuk dikaji yakni tentang bagaimana peraturan perundang-undangan di Indonesia serta hukum Islam mampu untuk mengatasi permasalahan sosial terutama prostitusi online di era globalisasi sekarang. Tulisan ini mengkaji tentang sanksi prostitusi online melalui media sosial perspektif hukum Islam.

\section{Pengertian Prostitusi Online}

Prostitusi di Indonesia dianggap sebagai kejahatan terhadap moral/kesusilaan. Kegiatan prostitusi adalah sebuah kegiatan yang ilegal dan bersifat melawan hukum. Kejahatan sudah ada sejak dahulu kala di dalam suatu masyarakat dan dapat dikatakan sebagai suatu penyakit masyarakat. Menurut pendapat Kartini Kartono, crime atau kejahatan adalah bentuk tingkah laku yang bertentangan dengan moral kemanusiaan, merugikan masyarakat, dan melanggar hukum serta undang-undang pidana. ${ }^{10}$

Prostitusi atau disebut juga dengan pelacuran berasal dari kata lacur yang berarti malang, celaka, sial, gagal, atau buruk laku. Pelacur adalah perempuan yang melacur, sundal, wanita tuna susila. ${ }^{11}$ Kata prostitusi berasal dari perkataan Latin prostituere yang artinya menyerahkan diri dengan terang-terangan kepada perzinahan. Secara etimologi, pernah pula dihubungkan dengan perkataan prostare, artinya: menjual, menjajakan. Perkataan itu sejak zaman dahulu telah dipakai dalam perpustakaan Yunani Romawi untuk wanita-wanita yang menjual tubuhnya.

Prostitusi adalah suatu gejala yang terdapat di seluruh dunia dengan cara yang sangat berlain-lainan. Di kebanyakan negeri, pelacuran itu dilakukan secara gelap di rumah-rumah pelacuran dan di rumah-rumah "pertemuan". ${ }^{12}$ Profesor W. A. Bonger dalam tulisannya

\footnotetext{
${ }^{9}$ Simandjuntak, Patologi Sosial (Bandung: Tarsito, 1985), 113.

${ }^{10}$ Kartini Kartono, Patologi Sosial, (Jakarta: CV Rajawali, 1988), 137.

${ }^{11}$ W.J.S Poerdarmita, Kamus Umum Bahasa Indonesia, (Jakarta: PN Balai Pustaka 1984), 548.

${ }^{12}$ B. Simandjuntak, Patologi Sosial, 112.
} 
"Maatschappelijke Oorzaken der Prostitutie" menulis definisi prostitusi sebagai berikut: ${ }^{13}$

"Prostitusi ialah kemasyarakatan di mana wanita menjual diri melakukan perbuatan-perbuatan seksual sebagai mata pencarian. Pada definisi ini jelas dinyatakan adanya peristiwa penjualan diri sebagai "profesi" atau mata pencarian sehari-hari, dengan jalan melakukan relasi-relasi seksual. ${ }^{14}$

Jadi yang dimaksud prostitusi online itu sendiri adalah gejala kemasyarakatan di mana wanita menjual diri, melakukan perbuatan seksual sebagai mata pencaharian dan media sosial sebagai alat untuk membantu bernegosiasi harga dan tempat dilakukannya prostitusi tersebut.

Mereka yang terlibat dalam praktek prostitusi online adalah:

1. Mucikari

Mucikari dalam Kamus Besar Bahasa Indonesia adalah induk semang bagi perempuan lacur atau germo. ${ }^{15}$ Namun pemahaman masyarakat secara luas adalah orang yang berperan sebagai pengasuh, perantara, an "pemilik" pekerja seks komersial (PSK). Dalam kebanyakan bisnis seks, khususnya yang bersifat massal, pekerja seks biasanya tidak berhubungan langsung dengan pengguna jasa. Mucikari berperan sebagai penghubung kedua pihak ini dan akan mendapat komisi dari penerimaan PSK yang prosentasenya dibagi berdasarkan perjanjian. Mucikari biasanya amat dominan dalam mengatur hubungan ini, karena banyak PSK yang "berhutang budi" kepadanya. Banyak PSK yang diangkat dari kemiskinan oleh mucikari, walaupun dapat terjadi eksploitasi oleh mucikari kepada anak asuhnya. Seperti ini pula mucikari dalam dunia prostitusi online, mereka hanya sebagai penghubung antara pekerja seks komersial dengan lelaki hidung belang.

2. Pekerja seks komersial (PSK)

PSK atau yang disebut dengan pelacur adalah praktek hubungan seksual sesaat, yang kurang lebih dilakukan dengan siapa saja untuk imbalan berupa uang. ${ }^{16}$ PSK dalam dunia online ada macamnya, ada yang secara langsung tanpa adanya perantara mucikari dengan menawarkan diri dan ada yang memang menggunakan pihak lain dalam hal ini adalah seorang mucikari.

\footnotetext{
${ }^{13}$ Kartini Kartono, Patologi Sosial, 205.

${ }^{14}$ Ibid., 182.

${ }^{15}$ Umi Chulsum, Kamus Besar Bahasa Indonesia, (Surabaya: Kashiko, 2006), 473.

${ }^{16}$ Thanh-Dam Truong, Seks, Uang dan Kekuasaan, (Jakarta: LP3ES, 1992), 15.
} 


\section{Pihak penyewa jasa PSK}

Dari semua pihak yang disebutkan, pihak penyewa inilah yang menjadi titik permasalahan terjadinya transaksi prostitusi online. Walaupun tentu pihak lain juga memberikan dorongan hingga terjadinya praktek prostitusi ini. Namun pihak penyewa inilah yang menjadi target bagi pemilik website atau forum prostitusi online untuk menyewa PSK darinya.

\section{Cara Kerja Prostitusi Online}

Para pelaku prostitusi online, baik pada gadis ABG maupun para pria hidung belang, mengaku lebih suka memilih cara online dari pada datang langsung dan memilih-milih di jalanan. Dengan sistem online semuanya menjadi lebih mudah bahkan tinggal memilih jenis dan ukuran harga yang diinginkan. Para wanita panggilan kerap sekali menggunakan media sosial seperti twitter dan facebook untuk mempromosikan dirinya kepada para lelaki hidung belang yang hendak mencari kepuasan ranjang. Setelah berhubungan melalui twitter atau facebook kemudian percakapan serius dilanjutkan dengan BBM atau Whatsapp.

Mengapa para gadis ABG ini lebih memilih cara seperti ini lantaran lebih mudah dan lebih aman, seperti ini mekanisme cara kerja prostitusi online di antaranya yaitu: ${ }^{17}$

1. Pekerja seks komersial akan mempromosikan dirinya melalui media sosial.

2. Pria hidung belang menemukan iklan PSK tersebut kemudian berhubungan melalui media sosial dan disambungkan dengan BBM atau Whatsapp setelah ada kata deal ingin bertemu.

3. Biasanya, sebelum deal, pria hidung belang diharapkan memberi Dp (uang muka) terlebih dahulu untuk meyakinkan PSK

4. Dalam iklan yang dipromosikan di media sosial, para PSK sudah menentukan secara detail layanan yang akan diterima oleh para pria hidung belang tersebut.

5. Setelah berhubungan melalui BBM atau Whatsapp, maka akan ditentukan di mana tempat pelaksanaannya.

6. Setelah selesai, biasanya lelaki hidung belang akan langsung meminta nomor handphone untuk mempermudah memanggilnya kembali suatu saat jika membutuhkan.

17 "Beginilah Cara Kerja Prostitusi Online" http://www.laporpolisi.com/2203/beginilah-caraprostitusi-online-beraksi, diakses tanggal 14 Desember 2015. 


\section{Sanksi Mucikari menurut Kitab Undang-Undang Hukum Pidana}

Kejahatan Prostitusi secara umum diatur dalam Buku II KUHP Bab XIV tentang Kejahatan terhadap Kesusilaan dan Buku III KUHP Bab II tentang Pelanggaran Ketertiban Umum.

Pembahasan terhadap mucikari atau germo terdapat dalam KUHP dan RUU-KUHP. Tidak sedikit peran mucikari terhadap pemasaran pornografi (misal, VCD porno) dan pornoaksi, khususnya untuk para pelanggan mereka sebagai salah satu bagian pelayanan dalam memberikan kepuasan kepada para konsumen atau pelanggan.

KUHP tidak melarang prostitusi, dan RUU-KUHP hanya melarang prostitusi yang bergelandangan dan berkeliaran di jalan dan di tempat umum. Tetapi KUHP dan RUU-KUHP melarang mucikari. Pasal RUU-KUHP melarang orang yang bergelandangan dan berkeliaran di jalan atau di tempat umum dengan tujuan melacurkan diri, seperti telah dikemukakan, namun pelacuran atau prostitusi itu sendiri tidak dilarang. Jika RUU-KUHP melarang prostitusi, tentu larangan melacurkan diri itu tidak terbatas hanya untuk orang yang bergelandangan dan berkeliaran di jalan dan di tempat umum saja, atau di tempat terbuka saja. Tentunya pelacuran dalam bentuk apapun, dilakukan oleh siapa pun, dan di tempat mana pun, termasuk tempat tertutup sekalipun tetap harus dilarang. Tetapi kenyataannya tidak demikian, tidak ada satu pasal pun yang melarang pelacuran di tempat tertutup. Hal itu dapat dilihat dalam pasalpasal yang mengatur tentang Kejahatan Terhadap Kesusilaan dalam Buku Kedua Bab XIV KUHP Pasal 281-Pasal 299, tentang Pelanggaran Kesusilaan dalam Buku Ketiga Bab VI KUHP Pasal 532 sampai dengan Pasal 535.

Adapun penjelasan mengenai tindak pidana tentang prostitusi yang terdapat dalam KUHP adalah:

a. Pasal 296 Buku II KUHP tentang Kejahatan Terhadap Kesusilaan, yang berbunyi: ${ }^{18}$

"Barang siapa dengan sengaja menyebabkan atau memudahkan cabul oleh orang lain dengan orang lain, dan menjadikannya sebagai pencarian atau

\footnotetext{
${ }^{18}$ Moeljatno, Kitab Undang-Undang Hukum Pidana, (Jakarta: Sinar Grafika Offset, 2008), 108.
} 
kebiasaan, diancam dengan pidana penjara paling lama satu tahun empat bulan atau pidana denda paling banyak lima belas ribu rupiah".

b. Pasal 506 Buku III KUHP tentang Pelanggaran Ketertiban Umum, yang berbunyi: ${ }^{19}$

"Barang siapa mengambil keuntungan dari perbuatan cabul seorang wanita dan menjadikannya sebagai mata pencaharian, diancam dengan pidana kurungan paling lama satu tahun”.

Dengan kata "barang siapa" yang berarti maksudnya kepada orangorang yang menjadi mucikari. Orang yang menjadi prantara antara pekerja seks komersial (PSK) dan mereka yang menggunakan jasanya.

Inti dari kedua pasal di atas adalah sama, yaitu hanya menghukum mereka yang mencari keuntungan dalam praktek prostitusi ini yakni mucikari. Dalam KUHP ini tidak mengatur tentang pihak seperti pemilik website. Mengenai pekerja seks komersial, KUHP menyebutkannya sebagai pesenggamaan atas dasar suka sama suka, yang dilakukan oleh seseorang dengan orang yang telah bersuami atau beristri (permukahan), meskipun ujung dari praktek prostitusi online adalah adanya hubungan seks terlarang ini.

Menurut pasal $284 \mathrm{KUHP}$, jika permukahan itu terjadi, maka orang yang dapat mengadukan tindak pidana permukahan adalah hanya suami atau istri yang tercemar. Menurut pasal-pasal tersebut, tindak pidana permukahan atau perzinaan adalah merupakan delik aduan, bukan delik biasa.

\section{Sanksi Mucikari menurut Undang-Undang RI Nomor 11 Tahun 2008 tentang Informasi dan Transaksi Elektronik}

Kehadiran undang-undang di sebuah negara berfungsi untuk mengatur maupun untuk melindungi masyarakatnya. Pada dasarnya undang-undang itu lahir sebelum permasalahan itu timbul, harapannya untuk melindungi masyarakat dari permasalahan yang akan terjadi. Perkembangan lingkungan, budaya dan teknologi membuat perubahan atas tata kehidupan masyarakat. Kemajuan teknologilah yang menyebabkan perubahan terbesar dari tata kehidupan masyarakat tersebut, semua dipermudah dengan kehadiran teknologi.

Negara Indonesia yang menjadi negara berkembang, tidak ketinggalan dalam menikmati atau menggunakan teknologi yang semakin canggih dan yang semakin pesat berkembang di antaranya adalah internet.

${ }^{19} \mathrm{lbid} ., 184$. 
Selain bertujuan untuk mempermudah kehidupan dalam berkegiatan sehari-hari, banyak juga yang menyalahgunakan teknologi tersebut, seperti halnnya yang penulis bahas yakni tentang praktek prostitusi dalam praktik prostitusi melalui jaringan internet.

Tahun 2003, pemerintah mengatur tentang kegiatan melalui media internet ini dengan nama RUU Informasi Komunikasi dan Transaksi Elektronik yang sekarang menjadi Undang-Undang RI Nomor 11 Tahun 2008 tentang Informasi dan Transaksi Elektronik (UU ITE).

UU ITE mulai dirancang pada bulan maret 2003 oleh Kementerian Negara Komunikasi dan Informasi (KOMINFO). Pada mulanya, RUU ITE diberi nama undang-Undang Informasi Komunikasi dan Transaksi Elektronik oleh Departemen Perhubungan, Departemen Perindustrian, Departemen Perdagangan, serta bekerja sama dengan Tim dari universitas yang ada di Indonesia yaitu Universitas Padjajaran (Unpad), Institut Teknologi Bandung (ITB) dan Universitas Indonesia (UI).

Pada tanggal 5 september 2005, secara resmi presiden Susilo Bambang Yudhoyono menyampaikan RUU ITE kepada DPR melalui surat No.R/70/Pres/9/2005 dan menunjuk Dr. Sofyan A Djalil (Menteri Komunikasi dan Informatika) dan Mohammad Andi Mattalata (Menteri Hukum dan Hak Asasi Manusia) sebagai wakil pemerintah dalam pembahasan bersama dengan DPR RI.

Tanggal 24 Januari 2007 sampai dengan 6 Juni 2007, Pansus DPR RI dengan pemerintah yang diwakili oleh Dr. Sofyan A Djalil (Menteri Komunikasi dan Informatika) dan Mohammad Andi Mattalata (Menteri Hukum dan Hak Asasi Manusia) membahas DIM RUU ITE.Tanggal 29 Juni 2007 sampai dengan 31 Januari 2008 pembahasan RUU ITE dalam tahapan pembentukan dunia kerja (panja), sedangkan pembahasan RUU ITE tahap Tim Perumus (Timus) dan Tim Sinkronisasi (Timsin) yang berlangsung sejak tanggal 13 Februari 2008 sampai dengan 13 Maret 2008. Tanggal 18 Maret 2008, naskah akhir UU ITE dibawa ke tingkat II sebagai pengambilan keputusan. 25 Maret 2008, 10 Fraksi menyetujui RUU ITE ditetapkan menjadi Undang-Undang. Selanjutnya Presiden Susilo Bambang Yudhoyono menandatangani naskah UU ITE menjadi Undang-Undang Republik Indonesia Nomor 11 Tahun 2008 tentang 
Informasi dan Transaksi Elektronik, dan dimuat dalam Lembaran Negara Nomor 58 Tahun 2008. ${ }^{20}$

Kehadiran undang-undang tersebut menjadi sebuah harapan bagi masyarakat Indonesia agar mereka dapat terlindung dari kegiatan-kegiatan yang dilakukan dari media internet salah satunya yaitu prostitusi melalui media sosial. Dan undang-undang ini mengatur tentang sanksi terhadap tindakan kriminal di dunia maya secara pidana.

Dalam Undang-Undang RI Nomor 11 Tahun 2008 tentang Informasi dan Transaksi Elektronik (ITE) tidak menyebutkan kata prostitusi dalam semua pasalnya. Kecuali pada pasal 27 yang berisikan tentang perbuatan-perbuatan yang dilarang, menyebutkan kata kesusilaan yang menyangkut kepada hal-hal yang berbau pornografi. Isi pasal $27 \mathrm{UU}$ ITE yaitu sebagai berikut: ${ }^{21}$

(1) Setiap orang dengan sengaja dan tanpa hak mendistribusikan dan/atau mentransmisikan dan/atau membuat dapat diaksesnya informasi elektronik dan/atau dokumen elektronik yang memiliki muatan yang melanggar kesusilaan.

(2) Setiap orang dengan sengaja dan tanpa hak mendistribusikan dan/atau mentransmisikan dan/atau membuat dapat diaksesnya informasi elektronik dan/atau dokumen elektronik yang memiliki muatan perjudian.

(3) Setiap orang dengan sengaja dan tanpa hak mendistribusikan dan/atau mentransmisikan dan/atau membuat dapat diaksesnya informasi elektronik dan/atau dokumen elektronik yang memiliki muatan penghinaan dan/atau pencemaran nama baik.

(4) Setiap orang dengan sengaja dan tanpa hak mendistribusikan dan/atau mentransmisikan dan/atau membuat dapat diaksesnya informasi elektronik dan/atau dokumen elektronik yang memiliki muatan pemerasan dan/atau pengancaman. ${ }^{22}$

Pada pasal 27 UU ITE, tepatnya pada ayat (1) menyebutkan kata kesusilaan yang dimaksudkan menyangkut pada hal-hal yang bersifat kepornoan. Pada ayat ini tidak menyebutkan hal-hal apa sajakah yang dimaksud kesusilaan tersebut. Ketentuan Undang-Undang No.11 tahun

20 "Dasar Pembentukan dan Penjelasan Undang-undang Informasi dan Transaksi Elektronik", dalam http://groupe5eptik.blogspot.co.id/2013/04/lengkap-tentang-uu-ite.html, diakses pada tanggal 24 Januari 2015.

${ }^{21}$ Undang-undang RI No. 11 tentang Informasi dan Transaksi Elektronik.

${ }^{22} \mathrm{lbid}$. 
2008 tentang Informasi dan Transaksi Elektronik tersebut dapat digunakan dalam perkara prostitusi online adalah Pasal 45 ayat (1) juncto Pasal 27 ayat $(1){ }^{23}$

Ketentuan Pasal 52 ayat (1) mengatur pemberatan sanksi pidana atas pelanggaran Pasal 27 ayat (1) yaitu mendistribusikan, mentransmisikan, dan/atau membuat dapat diaksesnya informasi elektronik dan/atau dokumen elektronik yang memiliki muatan melanggar kesusilaan menyangkut kesusilaan atau eksploitasi seksual terhadap anak. Sanksi pidana atas tindak pidana tersebut adalah pidana pokok sebagaimana diatur dalam Pasal 45 ayat (1) yaitu 6 tahun dan/atau denda Rp. 1 M ditambah sepertiga.

Ketentuan Pasal 52 ayat (1) termasuk pengaturan mengenai child pornography, yang di negara-negara di dunia, baik dalam hukum nasionalnya maupun hukum internasional, mendapat perhatian serius. Dalam konvensi Dewan Eropa 2001, child pornoghrapy juga diatur dan merupakan salah satu jenis tindak pidana yang harus diharmonisasi dan diatur dalam hukum nasional negara-negara pratifikasi. Pemberatan pidana atas tindak pidana child pornoghrapy sangat diperlukan untuk memberikan perlindungan kepada anak yang mempunyai kedudukan sangat rentan dan mempunyai peran yang sangat penting untuk kehidupan manusia di masa yang akan datang, baik kehidupan anak tersebut maupun kehidupan manusia pada umumnya. Di beberapa negara maju, sanksi pidana terhadap pelaku child pornoghrapy umumnya relatif lebih berat. ${ }^{24}$

Pada pasal 27 ayat (1) tersebut menyebutkan "Setiap orang dengan sengaja dan tanpa hak mendistribusikan dan/atau mentransmiikan dan/atau membuat dapat diaksesnya informasi elektronik dan/atau dokumen elektronik...", sehingga yang menjadi subyek hukum yang dituntut pertanggungjawaban pidananya dalam UU ini hanyalah pemilik website prostitusi online, yakni sebagai orang yang mendistribusikan atau mentransmisikan atau membuat dapat diaksesnya situs-situs porno atau prostitusi online tersebut.

Ketentuan mengenai sanksi dalam UU ITE ini termuat, yaitu pada Pasal 45 ayat (1) tentang ketentuan pidana: Setiap Orang yang memenuhi

\footnotetext{
${ }^{23}$ Widodo, Hukum Pidana di Bidang Teknologi Informasi (Cybercrim Law), (Yogyakarta: Aswaja Pressindo, 2013), 137.

${ }^{24}$ Sigid Suseno, Yurisdiksi Tindak Pidana Siber, (Bandung: PT Refika Aditama, 2012), 180.
} 
unsur sebagaimana dimaksud dalam Pasal 27 ayat (1), ayat (2), ayat (3), atau ayat (4) dipidana dengan pidana penjara paling lama 6 tahun dan atau denda paling banyak Rp.1.000.000.000,00. ${ }^{25}$ Pasal ini mengancam penjatuhan pidana bagi setiap orang yang melakukan beberapa kejahatan, yang salah satunya Pasal 27 ayat (1) mengenai kesusilaan dengan pidana penjara maksimal 6 tahun dan/atau denda maksimal 1 miliar rupiah.

\section{Sanksi Prostitusi Online melalui Media Sosial menurut Hukum Islam}

Menurut hukum Islam sangat jelas, bahwa perbuatan zina dilarang dan sanksinya ditentukan langsung dalam syariat Islam secara qath'iy, yaitu al-Qur'an dan hadis nabi Muhammad saw. Menurut surat an-Nur ayat 2:

"Perempuan yang berzina dengan laki-laki yang berzina, hendaklah kamu dera tiap-tiap satu dari keduanya itu dengan seratus kali deraan. Dan janganlah kamu dipengaruhi oleh perasaan kasihan kepada keduanya di dalam menjalankan (ketentuan) agama Allah yaitu jika kamu sebenarnya beriman kepada Allah dan hari akhirat. Dan hendaklah hukuman keduanya itu disaksikan oleh sekumpulan orang-orang yang beriman”. ${ }^{26}$

Dalam hukum Islam, zina adalah pebuatan yang sangat tercela dan pelakunya dikenakan sanksi yang amat berat, baik itu hukum dera maupun rajam, karena alasan yang dapat di pertanggung jawabkan secara moral dan akal. Pelaku zina diancam dengan hukuman berat. Pelakunya dihukum dengan hukuman rajam (dilempari batu sampai meninggal dengan disaksikan banyak orang), jika muhshan. Jika ia ghairu muhshan, maka ia dihukum cambuk 100 kali. Adanya perbedaan hukuman tersebut karena muhshan seharusnya bisa lebih menjaga diri untuk melakukan perbuatan tercela itu, apalagi kalau masih dalam ikatan perkawinan yang berarti menyakiti dan mencemarkan nama baik keluarganya, sementara ghairu muhshan belum pernah menikah sehingga nafsu syahwatnya lebih besar karena didorong rasa keingintahuannya. Namun keduanya tetap sangat dicela oleh Islam dan tidak boleh diberi belas kasihan. ${ }^{27}$ Hukuman tersebut merupakan bagian dari hukuman hudûd, karena telah ada ketentuannya dengan jelas pada nash.

Larangan melakukan pekerjaan mucikari, berkaitan dengan larangan terhadap perdagangan perempuan, baik dewasa maupun anak-

\footnotetext{
${ }^{25}$ Undang-undang RI Nomor 11 Tahun 2008 tentang Informasi dan Transaksi Elektronik. ${ }^{26}$ Departemen Agama RI, Al-Qur'an dan Tafsirnya, 589.

${ }^{27}$ A. Djazuli, Fiqh Jinayah, (Jakarta: PT Raja Grafindo Persada, 1997), $42-43$.
} 
anak. ${ }^{28}$ Dalam hukum Islam, berdasarkan ketentuan dalam surat an-Nur ayat 33, pekerjaan mucikari adalah haram hukumnya. Lebih-lebih dalam pekerjaannya itu para mucikari disertai dengan menyediakan benda-benda pornografi atau perbuatan pornoaksi, sebagai pelayanan bagi konsumen atau pelanggan. ${ }^{29}$

"Dan janganlah kamu paksa budak-budak perempuanmu melakukan pelacuran (al-bighâ), sedangkan mereka sendiri menginginkan kesucian, karena kamu hendak mencari keuntungan duniawi. Dan barang siapa yang memaksa mereka, maka sesungguhnya Allah adalah Maha Pengampun dan Maha Penyayang (kepada mereka yang dipaksa melakukan pelacuran) sesudah mereka dipaksa itu." ${ }^{30}$

Larangan melakukan pekerjaan mucikari dalam surat an-Nur ayat 33 didahului oleh perintah dalam surat an-Nur ayat 32, agar kita mengawinkan atau menganjurkan orang-orang yang berstatus sendirian melakukan perkawinan. Dan jika mereka miskin, menurut ayat 32 tersebut, Allah akan memampukan mereka dengan karunia-Nya.

Pada awal ayat 33 surat an-Nur dikemukakan bahwa bagi orang yang tidak mampu melakukan perkawinan hendaklah menjaga kesucian dirinya, sehingga Allah memberikan kemampuan kepada mereka melalui karunia-Nya. Kaitan antara surat an-Nur ayat 32 dan 33 adalah sangat berkaitan, karena kedua ayat tersebut mengatur agar orang menjaga kesucian dirinya dari perbuatan zina melalui lembaga perkawinan. Dalam perintah Allah tersebut mngandung larangan berbuat zina. Selain larangan melakukan tindak pidana perzinaan, dalam ayat 33 secara tegas diatur pula tentang larangan melakukan pekerjaan mucikari yang menyediakan pelacur untuk perzinaan dan pelacuran.

Dalam surat an-Nur ayat 33 tidak diatur secara jelas tentang sanksi terhadap mucikari, meskipun demikian, tidak berarti bagi para mucikari tidak ada hukumannya. Sanksi terhadap mereka dapat ditentukan melalui lembaga ta'zîr, karena setiap perbuatan maksiat yang tidak dapat dikenai sanksi hudûd (termasuk di dalamnya qishâsh) atau kaffarah dikualifikasikan sebagai jarîmah ta'zî. ${ }^{31}$ Dengan ukuran dan jenis sanksi yang preventif, agar mereka jera dan tidak berusaha mengulangi perbuatan maksiat itu lagi. Misalnya, selain dijatuhi hukuman penjara, ia juga

\footnotetext{
${ }^{28}$ Neng Djubaedah, Pornografi dan Pornoaksi ditinjau dari Hukum Islam, 200.

${ }^{29}$ Ibid., 210.

${ }^{30}$ Departemen Agama RI, Al-Qur'an dan Tafsirnya, 625-626.

${ }^{31}$ Jaih Mubarak dan Enceng Arif Faizal, Kaidah Figh Jinayah (Asas-asas Hukum Pidana Islam), 176.
} 
dijatuhi hukuman denda berupa sejumlah uang halal yang wajib dibayar kepada korban, atau berupa restitusi. ${ }^{32}$ Sanksi atas perbuatan mucikari yang melakukan tindak pidana tersebut seharusnya lebih berat, yaitu berupa adzab yang pedih, karena ia telah melakukan dosa besar.

Penetapan kadar sanksi ta'zîr asalnya merupakan hak bagi Khalifah. Meskipun demikian sanksi ta'zîr boleh ditetapkan berdasarkan ijtihad seorang qâhily. Boleh juga Khalifah melarang qâdhiy untuk menetapkan ukuran sanksi ta'zîr, dan khalifah sendiri yang menetapkan ukuran sanksi ta'zîr-nya kepada qâdhiy. Sebab qâdhiy adalah wakil khalifah. Sedangkan peradilan bergantung pada zaman, tempat, dan kasus yang terjadi. Khalifah boleh memberi hak khusus kepada qâdhiy untuk memutuskan persoalan-persoalan peradilan tertentu. Khalifah juga yang berhak melarang qâdhiy untuk menetapkan sanksi ta'zîr secara mutlak. Bahkan Khalifah boleh melarang qâdhiy menetapkan ukuran sanksi ta'zîr pada sebagian kasus peradilan, kemudian memberikan hak kepada qâdhiy pada kasus-kasus yang lain. ${ }^{33}$

Mucikari sangat sering ditemukan dalam masyarakat. Namun, karena pekerjaan mucikari biasanya dilakukan secara sembunyi-sembunyi, maka anggota masyarakat setempat sulit untuk melakukan pengaduan, meskipun tindak pidana mucikari ini merupakan delik biasa atau delik umum.

Selain itu, tindak pidana mucikari juga merupakan lembaga yang melestarikan perbudakan. Seperti telah diketahui, perbudakan adalah perbuatan yang dilarang, baik dalam hukum Islam, hukum Barat, ataupun hukum adat di Indonesia. Orang-orang yang dijadikan objek pekerjaan mucikari tentu orang-orang yang tidak bebas, teraniaya dan harga dirinya tidak dihormati. Padahal menurut ajaran Islam, dalam surat al-Isra ayat 70, Allah memuliakan umat manusia ciptaan-Nya, termasuk orang-orang yang dijadikan pelacur sebagai objek pekerjaan para mucikari dan para mucikari itu sendiri, "dan sesungguhnya telah Kami muliakan anak-anak Adam." Namun manusia itu sendiri (para mucikari) yang menganiaya dirinya sendiri, hanya karena faktor duniawi semata, faktor kesenangan sesaat. $^{34}$

\footnotetext{
${ }^{32}$ Neng Djubaedah, Pornografi dan Pornoaksi ditinjau dari Hukum Islam, 201.

${ }^{33}$ Abdurrahman al-Maliki, Sistem Sanksi dalam Islam, (Bogor: Dar al-Ummah, 2002), 245.

${ }^{34}$ Ibid., 201
} 
Sanksi prostitusi online di Indonesia dalam hukum Positif dijelaskan hukuman untuk seorang mucikari yaitu terdapat dalam Kitab Undang-Undang Hukum Pidana dan Undang-Undang Nomor 11 Tahun 2008 tentang Informasi dan Transaksi Elektronik. Adapun penjelasan mengenai Tindak Pidana tentang Prostitusi yang terdapat dalam KUHP Pasal 296 Buku II KUHP tentang Kejahatan Terhadap Kesusilaan dan Pasal 506 Buku III KUHP tentang Pelanggaran Ketertiban Umum. Inti dari kedua pasal di atas adalah sama, yaitu hanya menghukum mereka yang mencari keuntungan dalam praktek prostitusi ini yakni mucikari.

Mengenai pekerja seks komersial dalam Kitab Undang-undang Hukum Pidana menyebutkannya sebagai pesenggamaan atas dasar suka sama suka, yang dilakukan oleh seseorang dengan orang yang telah bersuami atau beristri (permukahan). Dan menurut pasal 284 KUHP yang berbunyi: "dihukum penjara selama-lamanya sembilan bulan, 1a) bagi laki laki yang beristri, berbuat zina sedang diketahuinya, bahwa pasal 27 KUHPerdata berlaku padanya, b perempuan yang bersuami berbuat zina, 2a) laki-laki yang turut melakukan perbuatan itu sedang diketahuinya bahwa kawannya itu bersuami, b) perempuan yang tiada bersuami yang turut melakuan perbuatan itu, sedangkan diketahuinya bahwa kawannya itu beristri dan pasal 27 KUHPerdata berlaku pada kawannya." Dan jika permukahan itu terjadi, maka orang yang dapat mengadukan tindak pidana permukahan adalah hanya suami atau istri yang tercemar. Menurut pasal-pasal tersebut, tindak pidana permukahan atau perzinaan adalah merupakan delik aduan, bukan delik biasa.

Dalam Undang-Undang RI Nomor 11 Tahun 2008 tentang Informasi dan Trnsaksi Elektronik (ITE) tidak menyebutkan kata prostitusi dalam semua pasalnya. Kecuali pada pasal 27 yang berisikan tentang perbuatan-perbuatan yang dilarang, menyebutkan kata kesusilaan yang menyangkut kepada hal-hal yang berbau pornografi. Pada pasal 27 UU ITE, tepatnya pada ayat (1) menyebutkan kata kesusilaan yang dimaksudkan menyangkut pada hal-hal yang bersifat kepornoan. Pada ayat ini tidak menyebutkan hal-hal apa sajakah yang dimaksud kesusilaan tersebut. Dalam pasal 27 ayat (1) yang menjadi subyek hukum yang di tuntut pertanggungjawaban pidananya dalam Undang-undang ini hanyalah pemilik website.

Ketentuan mengenai sanksi dalam UU ITE ini termuat, yaitu pada Pasal 45 ayat (1) tentang ketentuan pidana: Setiap orang yang memenuhi 
unsur sebagaimana dimaksud dalam Pasal 27 ayat (1), ayat (2), ayat (3), atau ayat (4) dipidana dengan pidana penjara paling lama 6 tahun dan atau denda paling banyak Rp.1.000.000.000,00. Pasal ini mengancam penjatuhan pidana bagi setiap orang yang melakukan beberapa kejahatan, yang salah satunya Pasal 27 ayat (1) mengenai prostitusi online dengan pidana penjara maksimal 6 tahun dan/atau denda maksimal 1 miliar rupiah.

Dalam hukum Positif pada Kitab Undang-Undang Hukum Pidana, pada pasal 296 seorang Mucikari diancam dengan pidana penjara paling lama satu tahun empat bulan atau pidana denda paling banyak lima belas ribu rupiah, dan pada pasal 506 diancam dengan pidana kurungan paling lama satu tahun. Kemudian dalam Undang-Undang Nomor 11 Tahun 2008 tentang Informasi dan Transaksi Elektronik seorang mucikari apabila ia tanpa hak mendistribusikan dan/atau mentransmisikan dan/atau membuat dapat diaksesnya Informasi Elektronik dan/atau Dokumen Elektronik yang memiliki muatan yang melanggar kesusilaan diancam dengan pidana penjara paling lama 6 tahun dan atau denda paling banyak Rp.1.000.000.000,00.

Mengenai kedua Undang-Undang tersebut apabila seorang mucikari dalam kasusnya ia dijerat dengan kedua undang-undang tersebut maka ia dikenai sanksi atau hukuman yang paling berat di antara kedua undang-undang yang menjeratnya tersebut. Seperti yang ditentukan dalam Kitab Undang-Undang Hukum Pidana pasal 64 ayat (1) yang berbunyi:

"Jika antara beberapa perbuatan, meskipun masing-masing merupakan kejahatan atau pelanggaran, ada hubungannya sedemikian rupa sehingga harus dipandang sebagai satu perbuatan berlanjut (voortgezette handeling) maka hanya dikenakan satu aturran pidana; jika berbeda-beda, yang dikenakan yang memuat ancaman pidana pokok yang paling berat.”

Dalam hukum Islam, sanksi bagi seorang PSK adalah dihukum dengan hukuman rajam (dilempari batu sampai meninggal dengan disaksikan banyak orang), jika muhshan. Jika ia ghair muhshan, maka ia dihukum cambuk 100 kali. Dan dalam surat an-Nur ayat 33 tidak diatur secara jelas tentang sanksi terhadap mucikari, meskipun demikian, tidak berarti bagi para mucikari tidak ada hukumannya. Sanksi terhadap mereka dapat ditentukan melalui lembaga ta'zîr, karena bahwa setiap perbuatan maksiat yang tidak dapat dikenai sanksi hudûd (termasuk di dalamnya qishâsh) atau kaffarah dikualifikasikan sebagai jarîmah ta'zîr. Dengan 
ukuran dan jenis sanksi yang preventif, agar mereka jera dan tidak berusaha mengulangi perbuatan maksiat itu lagi. Hukuman dalam jarîmah ta'zîr tidak ditentukan ukurannya atau kadarnya, artinya untuk menentukan batas terendah dan tertinggi diserahkan sepenuhnya kepada hakim. Dalam menetapkan jarîmah ta'zîr, prinsip utama yang menjadi acuan penguasa adalah menjaga kepentingan umum dan melindungi setiap anggota masyarakat dari kemudharatan (bahaya).

Mengenai prostitusi online secara umumnya, perbedaannya terletak pada pihak-pihak siapa saja yang dapat dikenai sanksi dalam hukum Positif dan hukum Islam tersebut. Di setiap Undang-Undang yang berlaku maupun hukum Islam yang mengatur tentang larangan mengenai kejahatan prostitusi adalah berbeda-beda, yang mana dalam Kitab Undang-Undang Hukum Pidana pihak-pihak yang dikenakan sanksi dalam praktek prostitusi online ini adalah mucikari, akan tetapi dalam hal ini para penyewa atau yang menggunakan jasa seorang psk ia bisa juga dikenai sanksi dengan delik aduan bagi mereka yang sudah menikah oleh pasangannya sendiri. Kemudian dalam Undang-Undang No.11 Tahun 2008 tentang Informasi dan Transaksi Elektronik hanya dapat menjerat pemilik website atau forum prostitusi online tersebut. Dalam Hukum Islam, pihak yang dapat dikenakan sanksi untuk kegiatan prostitusi online adalah siapa saja, jadi tidak ada pengecualian dalam hukum Islam bahwa siapa saja yang terlibat praktiek terlarang ini dapat dijatuhi sanksi.

Dalam Kitab Undang-Undang Hukum Pidana, sanksi yang diberikan bagi seorang mucikari relatif sedikit yang tidak memberi efek jera pada seorang mucikari tersebut dan juga tidak sebanding dengan apa yang ia lakukan dalam menjalankan bisnisnya sebagai seorang mucikari. Dalam Kitab Undang-Undang Hukum Pidana sendiri juga tidak mengatur larangan bagi seorang pengguna PSK maupun seorang PSK itu sendiri melainkan yang diatur dalam Kitab Undang-Undang Hukum Pidana hanyalah seorang mucikarinya saja.

Dalam Undang-Undang Nomor 11 Tahun 2008 tentang Informasi dan Transaksi Elektronik pada Pasal 27 tentang perbuatan yang terlarang yaitu pada ayat (1) muatan yang melanggar kesusilaan di sana tidak dijelaskan bagaimana standar kesusilaan itu sendiri ini bisa membuat sulit dan was-was bagi masyarakat dalam mengakses media sosial ataupun internet secara luas takut dianggap melanggar undang-undang yang berlaku. 
Kemudian mengenai sanksi dalam Undang-Undang Nomor 11 Tahun 2008 dengan pidana penjara paling lama 6 tahun dan atau denda paling banyak Rp.1.000.000.000,00, sanksi tersebut masih kurang berat, sebab denda maksimal Rp. 1 miliar yang masih relatif kecil jika dibandingkan dengan keuntungan yang dapat diperoleh dalam mengelola jaringan prostitusi online tersebut.

Menurut penulis, hukum ta'zîr sudah sesuai dengan apa yang seharusnya ditegakkan dalam memberantas adanya praktek prostitusi online itu sendiri. Dalam hukum Islam mengenai pihak-pihak yang terlibat dalam praktik prostutusi online semua pihak dapat dikenakan sanksi, jadi tidak ada pengecualian dalam hukum Islam bahwa siapa saja yang terlibat praktek terlarang ini dapat dijatuhi sanksi.

\section{Simpulan}

Prostitusi merupakan bentuk penyimpangan seksual, yang menyimpang dari nilai sosial, agama, dan moral bangsa Indonesia. Sedangkan prostitusi online merupakan bentuk dari kegiatan prostitusi yang dilakukan melalui media sosial maupun internet. Pengaturan tindak pidana dalam hukum positif di Indonesia terhadap sanksi prostitusi online dapat dijerat dengan menggunakan Kitab Undang-Undang Hukum Pidana yang terdapat dalam pasal 296 dan 506 bagi seorang mucikari kemudian mengenai seorang PSK Kitab Undang-undang Hukum Pidana menyebutkannya sebagai pesenggamaan atas dasar suka sama suka, yang dilakukan oleh seseorang dengan orang yang telah bersuami atau beristri (permukahan) sebagaimana yang terdapat dalam pasal 284 KUHP. Undang-Undang Nomor 11 Tahun 2008 tentang Informasi dan Transaksi Elektronik yang didalamnya telah diatur pada pasal 27 ayat (1) hanya membatasi larangan begi penyedia layanan seks komersial dan pemilik website semata. Menurut penulis, sanksi tersebut masih kurang berat, sebab denda maksimal Rp. 1 miliar yang masih relatif kecil jika dibandingkan dengan keuntungan yang dapat diperoleh dalam mengelola jaringan prostitusi online tersebut.

Dalam hukum Islam sanksi bagi seorang PSK adalah dihukum dengan hukuman rajam (dilempari batu sampai meninggal dengan disaksikan banyak orang) jika muhshan. Jika ia ghairu muhshan, maka ia dihukum cambuk 100 kali. Dalam surat an-Nur ayat 33 tidak diatur secara jelas tentang sanksi terhadap mucikari, meskipun demikian, tidak berarti 
bagi para mucikari tidak ada hukumannya. Sanksi terhadap mereka dapat ditentukan melalui lembaga ta'zîr, karena bahwa setiap perbuatan maksiat yang tidak dapat dikenai sanksi hudûd (termasuk di dalamnya qishâsh) atau kaffarah dikualifikasikan sebagai jarîmah ta'zîr. Dengan ukuran dan jenis sanksi yang preventif, agar mereka jera dan tidak berusaha mengulangi perbuatan maksiat itu lagi.

\section{Daftar Rujukan}

"Beginilah Cara Kerja Prostitusi Online" http://www.laporpolisi.com/2203/beginilah-cara-prostitusi-onlineberaksi, diakses tanggal 14 Desember 2015.

"Dasar Pembentukan dan Penjelasan Undang-undang Informasi dan Transaksi Elektronik", dalam http://groupe5eptik.blogspot.co.id/2013/04/lengkap-tentang-uuite.html, diakses pada tanggal 24 Januari 2015.

Al-Maliki, Abdurrahman. Sistem Sanksi dalam Islam. Bogor: Daar alUmmah, 2002.

Departemen Agama RI. Al-Qur'an dan Tafsirnya. Semarang: Wicaksana, 1994.

Djazuli, A. Fiqh Jinayah. Jakarta: PT Raja Grafindo Persada, 1997.

Djubaedah, Neng. Perzinaan dalam Peraturan Perundang-undangan di Indonesia Ditinjau dari Hukum Islam. Jakarta: Kencana, 2010. . Pornografi dan Pornoaksi Ditinjau dari Hukum Islam.

Jakarta: Kencana, 2009.

Kartono, Kartini. Patologi Sosial. Jakarta: CV Rajawali, 1988.

Moeljatno. Kitab Undang-Undang Hukum Pidana. Jakarta: Sinar Grafika Offset, 2008.

Mubarak, Jaih. dan Enceng Arif Faizal. Kaidah Fiqh Jinayah (Asas-asas Hukum Pidana Islam). Bandung: Pustaka Bani Quraisy, 2004.

Chulsum, Umi. Kamus Besar Bahasa Indonesia. Surabaya: Kashiko, 2006. Muslich, Ahmad Wardi. Hukum Pidana Islam. Jakarta: Sinar Grafika, 2005.

Poerdarmita, WJS. Kamus Umum Bahasa Indonesia. Jakarta: PN Balai Pustaka 1984.

Simandjuntak. Patologi Sosial. Bandung: Tarsito, 1985.

Suseno, Sigid. Yurisdiksi Tindak Pidana Siber. Bandung: PT Refika Aditama, 2012.

Trisnadi. Dolly Hitam Putih Prostitusi. Surabaya: Gagas Media, 2004. 
Truong, Thanh-Dam. Seks, Uang dan Kekuasaan. Jakarta: LP3ES, 1992. Undang-undang RI Nomor 11 Tahun 2008 tentang Informasi dan Transaksi Elektronik.

Widodo. Hukum Pidana di Bidang Teknologi Informasi (Cybercrim Law). Yogyakarta: Aswaja Pressindo, 2013. 